\title{
PENGARUH PEMBERIAN VIDEO AUDIO VISUAL AIDS (AVA) TERHADAP MOTIVASI KERJA DAN PENGETAHUAN PETUGAS PROMOSI KESEHATAN DI PUSKESMAS KOTA BANJARBARU
}

\author{
THE EFFECTS OF USING AUDIO VISUAL AIDS (AVA) WORK MOTIVATION \\ AND KNOWLEDGE OF HEALTH PROMOTION OFFICERS AT BANJARBARU \\ CITY HEALTH CENTERS
}

\author{
Azmi Yunarti ${ }^{*}$, Ratna Restapaty ${ }^{2}$, Liana Fitriani Hasymi ${ }^{3}$, Rahmayanti Fitriah ${ }^{4}$ \\ 1,2,3,4 Sekolah Tinggi Kesehatan Borneo Lestari \\ Jl. Kelapa Sawit 8 bumi Berkat Banjarbaru Indonesia \\ *Email :azmiiyunarti@gmail.com
}

\begin{abstract}
The implementation of Health Promotion in Public health center is very useful to increase insight and improve the ability of patients, patient families, and visitors at the Health Center to play a positive role in healing and prevention efforts against disease to accelerate the healing and rehabilitation process, improve PHBS, prevent disease, and as a work to advance public health degrees. The research design employed is a quasi experimental design (pseudo experiment) using a Pre-Test Post-Test With Control Group Design. Purposive sampling procedures were utilized in the sample research. The use of purposive sampling to identify differences in treatment between the control and experimental groups. The validity evaluation was done out in statistical reality. Based on the findings of the Wilcoxon test statistical analysis on work motivation variable $p=0.018$ and knower $p=0.011$, work motivation and knowledge $p$ (0.05 and HO rejected suggests that there is an influence between before and after treatment. The research found that AVA video media had an impact on job motivation and health promotion knowledge. Health promotion employees with excellent workmotivation in carrying out Health Promotion in public healt center effectively and optimally so that completing the target of obtaining success indicators in the deployment of health promotion to enhance public health degrees is easy.
\end{abstract}

Keywords: Video AVA; work motivation; knowledge health promotion

\begin{abstract}
ABSTRAK
Promosi Kesehatan di Puskesmas sangat bermanfaat menambah wawasan dan meningkatkan kemampuan pasien, keluarga pasien, dan pengunjung di Puskesmas tentang beragam jenis penyakit. Penelitian ini bertujuan untuk mengetahui adanya pengaruh pemberian media video Audio Visual Aids (AVA) terhadap meningkatkan motivasi kerja dan pengetahuan tenaga kesehatan sehingga dapat mempengaruhi kualitas dan kecakapan petugas dalam pelaksanaan promosi kesehatan di Puskesmas. Rancangan penelitian yang digunakan adalah quasi experimental design (eksperimen semu) dengan rancangan Pre-Test Post-Test With Control Grup Design. Sampel penelitian menggunakan teknik sampling purposive sampling. Berdasarkan hasil analisis statistik uji wilcoxon test pada variabel motivasi kerja $p$ $=0,018$ dan pengetahuan $p=0,011$, maka motivasi kerja dan pengetahuan $p<\alpha(0,05)$ dan Ho ditolak artinya terdapat pengaruh antara sebelum dan sesudah diberikan perlakuan yakni pemberian video AVA. Hasil penelitian menunjukan bahwa ada pengaruh pemberian media video AVA terhadap motivasi kerja dan pengetahuan promosi kesehatan. Petugas promosi kesehatan yang memiliki motivasi kerja tinggi dalam melaksanakan Promosi Kesehatan Puskesmas dengan baik dan optimal sehingga tidak sulit mencapai tujuan untuk pencapaian keberhasilan indikator keberhasilan dalam pelaksanaan promosi kesehatan untuk peningkatan derajat kesehatan masyarakat.
\end{abstract}

Kata Kunci: Video AVA; motivasi kerja; pengetahuan promosi kesehatan. 


\section{PENDAHULUAN}

Upaya dalam peningkatan derajat kesehatan masyarakat dipengaruhi oleh beberapa faktor salah satunya yakni faktor SDM. Faktor SDM diperlukan tenaga fungsional penyuluh kesehatan (PKM) untuk mengelola promosi kesehatan di Puskesmas. Keberadaan tenaga kesehatan yang berkualitas dan komunikatif sangat mempengaruhi tingkat keberhasilan pencapaian dalam peningkatan derajat kesehatan manusia (1). Promosi kesehatan merupakan suatu upaya dalam mewujudkan perilaku kesehatan yang berkesinambungan. Hal tersebut bearti bahwa perilaku kesehatan dilakukan secara terpadu, terintregasi dan berkaitan satu sama lain untuk memelihara dan meningkatkan derajat kesehatan masyarakat dalam bentuk pencegahan penyakit, peningkatan kesehatan, pengobatan penyakit, dan pemulihan kesehatan oleh pemerintah dan/atau masyarakat. Pemerintah daerah melakukan pembinaan terhadap masyarakat dengan memfasilitasi dan menyelenggarakan fasilitas kesehatan dan fasilitas pelayanan kesehatan. Fasilitas Pelayanan Kesehatan adalah suatu tempat yang digunakan untuk menyelenggarakan upaya pelayanan kesehatan, baik promotif, preventif, kuratif maupun rehabilitatif yang dilakukan oleh pemerintah daerah dan/atau masyarakat. Puskesmas mempunyai tugas melaksan (2).

Pelaksanaan promosi kesehatan dengan pemberdayaan terhadap individu, keluarga dan masyarakat yang dilaksanakan di Puskesmas dengan memperhatikan kondisi dan situasi, khususnya sosial budaya masyarakat setempat (3). Strategi promosi kesehatan harus diperkuat dengan metode dan media yang tepat, seta tersedianya sumber daya yang memadai. Promosi kesehatan memerlukan sumber daya manusia yang memahami akan fungsi dan pentingnya promosi kesehatan. Sumber daya manusia puskesmas memberikan andil terhadap semua kegiatan promosi kesehatan dalam mencapai tujuannya indikator keberhasilan, setiap tenaga kesehatan diharapkan memiliki motivasi kerja, dan pengetahuan yang tinggi sehingga nantinya dapat melaksanakan promosi kesehatan itu sesuai dengan yang telah diprogramkan. Penelitian ini bertujuan untuk mengetahui terdapat pengaruh pada pemberian media Video Audio Visual Aids (AVA) terhadap peningkatkan motivasi kerja dan pengetahuan tenaga promosi kesehatan tentang indikator keberhasilan dalam pelaksanaan promosi kesehatan di Puskesmas. Motivasi kerja merupakan salah satu faktor yang sangat penting untuk meningkatkan semangat dan integritas kerja tenaga kesehatan. Petugas promosi kesehatan yang memiliki motivasi kerja rendah cenderung tidak dapat melaksanakan program dengan baik, sebaliknya yang memiliki motivasi kerja tinggi akan dapat melaksanakan promosi kesehatan puskesmas dengan baik dan optimal. Hal tersebut menguatkan hasil penelitian sebelumnya menunjukan bahwa sebesar $64,1 \%$ disiplin kerja dan motivasi kerja secara simultan (bersama-sama) mempengaruhi kinerja karyawan (3). Berdasarkan hal tersebut, peningkatan motivasi kerja tenaga kesehatan non medis di puskesmas perlu dilakukan untuk meningkatkan kemampuan tenaga kesehatan dalam memberikan promosi kesehatan kepada pasien, keluarga dan pengunjung puskesmas agar dapat berperan secara positif dalam usaha penyembuhan dan pencegahan terhadap penyakit. Upaya peningkatan motivasi kerja, pengetahuan dalam pelaksanaan promosi kesehatan yakni dengan menggunakan media yang berbasis digital salah satunya dengan video Audio Visual Aids (AVA). Hal tersebut mendukung hasil penelitian lain yang menyatakan bahwa Audio Visual Aids, yaitu alat bantu pembelajaran yang mengkombinasikan antara gambar dan suara yang dapat dilihat, didengar, dibaca, dan dipergunakan dalam kegiatan belajar mengajar, serta memengaruhi efektivitas program intruksional. Video Audio Visual Aids (AVA) merupakan alat-alat yang membantu pendengaran dan pengelihatan (4). Motivasi kerja dan pengetahuan petugas promosi kesehatan yang meningkat dapat mempengaruhi kualitas dan kecakapan petugas tenaga kesehatan selama menjalankan peran dan fungsi berhasil melaksanakan promosi kesehatan di puskesmas. Sehingga dapat mempercepat proses penyembuhan serta rehabilitasi, meningkatkan PHBS, pencegahan terjadinya penyakit, meningkatkan derajat kesehatan masyarakat dapat terwujud.

\section{BAHAN DAN METODE}

Jenis penelitian ini penelitian kuantitatif dengan metode ekperimen semu (quasi eksperimen) dengan rancangan Pre-Test Post-Test With Control Grup Design. Pengumpulan data meliputi pretest, perlakuan sebanyak 2 kali dengan pemberian media 
Video Audio Visual Aids (AVA) dengan durasi selama 6 menit dilakukan dengan materi motivasi kerja, pengetahuan promosi kesehatan sesuai indikator keberhasilan promkes dan pemberian media Video Audio Visual Aids (AVA) dengan materi promkes secara umum, dan diakhiri dengan posttest. Instrumen dalam penelitian ini menggunakan kuesioner dan Video AVA. Teknik pengukuran instrumen menggunakan dua macam skala yakni Skala Likert dan skala gutman. Variabel penelitian yakni motivasi kerja sebagai variabel independent, variabel dependent adalah tingkat pengetahuan, promosi kesehatan. Kuesioner terlebih dahulu dilakukan uji validitas dan realibilitas. Uji statistik dalam penelitian ini adalah uji Wilcoxon Test. Audiovisual yang berupa video animasi mengenai motivasi kerja, dan pengetahuan. Video peneliti menggunakan video animasi yang di rancang sendiri sesuai dengan indikator pengukuran. Total dari video AVA tersebut yaitu 10: 00 menit. Video dibuat sesuai dengan ketentuan materi meliputi motivasi kerja dan pengetahuan promosi kesehatan. Hipotesis dalam penelitian ini yaitu ada perbedaan rerata antara motifasi kerja dan pengetahuan promosi kesehatan di Puskesmas. Uji wilcoxon test digunakan untuk mengetahui pengaruh pemberian intervensi video Audio Visual Aids (AVA). Populasi dalam penelitian ini adalah tenaga kesehatan di Puskesmas Banjarbaru non dokter di Puskesmas kota Banjarbaru sebanyak 349 petugas yang tersebar di 9 puskesmas. Sampel penelitian menggunakan teknik purposive sampling yakni menunjukkan perlakuan yang berbeda sehingga sampel diambil dua kelompok yaitu kelompok eksperimen dan kelompok control (5). Sampel sebanyak 60 tenaga kesehatan di Puskesmas, yang terbagi menjadi 2 kelompok; kelompok eksperimen sebanyak 30 responden dan kelompok kontrol sebanyak 30 responden. Pengambilan sampel tenaga kesehatan melaksanakan promosi kesehatan di dalam gedung Puskesmas (di tempat pendaftaran, poliklinik, ruang pelayanan KIA \& KB, ruangan perawatan inap, laboratorium, kamar obat, tempat pembayaran, klinik khusus, halaman) dan di luar gedung (kunjungan rumah, pemberdayaan berjenjang,dan pengorganisasian masyarakat). Uji validitas dilakukan di dengan jumlah sampel 30 responden yang menggunakan realbiliti statistic. dengan syarat jika $r$ hitung $\geq r$ tabel 0,361 maka data dikatakan valid, jika $r$ hitung $<\mathrm{r}$ tabel 0,361 maka data dikatakan tidak valid (5). Analsis Univariat dan Analisis Bivariat digunakan untuk mengetahui pengaruh antara variabel bebas dan terikat dengan analisis uji statistik menggunakan uji Chi-square.

\section{HASIL PEMBAHASAN}

Karakteristik Responden

Tabel 1. Karakteristik Responden Tenaga Kesehatan di Puskesmas Kota Banjarbaru

\begin{tabular}{|c|c|c|}
\hline Karakteristik Responden & $\mathbf{n}$ & $\%$ \\
\hline \multicolumn{3}{|l|}{ Pendidikan Terakhir } \\
\hline SMA/SMK & 4 & 6.7 \\
\hline D3 & 14 & 23.3 \\
\hline S1 & 38 & 63.3 \\
\hline S2 & 4 & 6.7 \\
\hline \multicolumn{3}{|l|}{ Masa Kerja } \\
\hline $1-10$ & 36 & 60.0 \\
\hline $10>$ & 24 & 40.0 \\
\hline \multicolumn{3}{|l|}{ Umur } \\
\hline 21-30 Tahun & 36 & 60.0 \\
\hline 31-40 Tahun & 18 & 30.0 \\
\hline 31-40 Tahun & 6 & 10,0 \\
\hline Total & 60 & 10.0 \\
\hline
\end{tabular}

menunjukkan bahwa pendidikan terakhir terbanyak yakni dengan a) pendidikan terakhir SMA/SMK sebanyak 4 orang (6.7\%), D3 sebanyak 14 orang (23.3\%) dan S1 sebanyak 38 orang (63.3\%), b) masa kerja $<10$ tahun berjumlah 36 orang $(60.0 \%)$ dan masa kerja $>10$ tahun berjumlah 24 orang $(40.0 \%)$, c) umur 21-30 tahun berjumlah 36 orang (60.0\%) dan umur 3140 berjumlah 18 (30\%), sedangkan untuk umur 4150 tahun berjumlah 6 orang (10\%).

Uji validitas dilakukan dengan jumlah sampel 30 responden dengan syarat jika $r$ hitung $\geq r$ tabel 0,361 maka data dikatakan valid. Sedangkan jika $r$ hitung $<r$ tabel 0,361 maka data dikatakan tidak valid.

Tabel 2. Hasil Perhitungan Statistik Reliability

\begin{tabular}{cc}
\hline $\begin{array}{c}\text { Koefisien } \\
\text { Alpha }\end{array}$ & Jumlah Item \\
\hline $\mathbf{0 , 9 5 5}$ & 37 \\
\hline
\end{tabular}

Tabel 2. menunjukkan bahwa hasil uji reliability 0,955 atau $\geq 0,60$ maka maka hasilnya reliabel. Hal tersebut sesui dengan teori bahwa Uji reabilitas penelitian menggunakan Rumus Alpha Cronbach, yaitu jika nilai Alpha Cronbach $\geq 0,60$ maka 
reliabel sebaliknya bila nilai Alpha Cronbach $<0,60$ maka tidak reliabel. Variabel motivasi kerja dengan indikator pengukurnya antara lain; menilai motivasi melalui; a) prestasi, b) pengakuan, c) pekerjaan itu sendiri, d) tanggung jawab, e) kemajuan, f) pengembangan potensi. Hasil motivasi sebelum dan sesudah diberi intervensi dengan media video AVA pada kelas eksperimen dilihat pada tabel 3 berikut.

Tabel 3. Hasil Pengaruh Pemberian video Audio Visual Aids (AVA) terhadap Motivasi Kerja Tenaga

\begin{tabular}{|c|c|c|c|c|}
\hline \multirow{2}{*}{ Motivasi kerja } & \multicolumn{2}{|c|}{ Sebelum } & \multicolumn{2}{|c|}{ Sesudah } \\
\hline & $\mathbf{n}$ & $\%$ & $\mathbf{n}$ & $\%$ \\
\hline Termotivasi & 26 & 86,6 & 100 & 100 \\
\hline Cukup Termotivasi & 4 & 13,3 & 0 & 0 \\
\hline Kurang termotivasi & 0 & 0 & 0 & 0 \\
\hline Total & 30 & 100 & 30 & 100 \\
\hline
\end{tabular}

Tabel 3. menunjukkan bahwa hasil analisis statistik uji wilcoxon test didapatkan $p=0,018$ maka $p<\alpha$ $(0,05)$ dan Ho ditolak artinya terdapat pengaruh yang signifikan sebelum dan sesudah diberikan antara perlakuan pada kelas eksperimen. Peningkatan sebelum dan sesudah diberi intervensi pada kategori termotivasi 86,6 \% sebelum dan sesudah sebesar 100\%, sedangkan kategori cukup termotivasi dari 13,3\% menjadi 0\%. Motivasi kerja sebagian besar responden termotivasi setelah melihat penayangan video Audio Visual Aids (AVA) selama 6 menit. Motivasi kerja dipengaruhi oleh kesempatan meningkatkan keterampilan dan kemampuan melaksanakan promosi kesehatan merupakan hal penting dalam mendapatkan prestasi, pengakuan dan penghargaan dari pimpinan dan teman sejawat. Faktor lain yang mempunyai peranan penting dalam peningkatan motivasi yaitu adnya hubungan dengan rekan kerja dan atasan, serta perhatian dari teman dan atasan memberikan pengaruh terhadap termotivasi atau tidaknya seorang tenaga kesehatan dalam bekerja (4). Selain hal tersebut, pengembangan potensi karir dengan ikut serta berbagai pelatihan yang mendukung pelaksanaan promosi kesehatan yang dilakukan sesuai prosedur. Hal tersebut sejalan dengan teori motivasi merupakan kesediaan individu mengeluarkan tingkat upaya tinggi ke arah tujuan organisasi yang dikondisikan oleh kemampuan upaya itu untuk memenuhi kebutuhan individual. Motivasi dapat memacu karyawan untuk bekerja keras sehingga dapat mencapai tujuan. Hal ini akan meningkatkan produktivitas kerja karyawan sehingga dapat berpengaruh terhadap pencapaian tujuan perusahaan (7). Simpulan hasil pengaruh pemberian video Audio Visual Aids (AVA) terhadap motivasi kerja tenaga kesehatan di Puskesmas pada kelompok kontrol di tabel berikut.

Tabel 4. Simpulan Hasil Pengaruh Pemberian Video AVA terhadap Motivasi Kerja Tenaga Kesehatan di Puskesmas pada Kelompok Kontrol

\begin{tabular}{|c|c|c|c|c|}
\hline \multirow[t]{2}{*}{ Motivasi Kerja } & \multicolumn{2}{|c|}{ Sebelum } & \multicolumn{2}{|c|}{ Sesudah } \\
\hline & $\mathbf{n}$ & $\%$ & $\mathbf{n}$ & $\%$ \\
\hline Termotivasi & 24 & 80 & 27 & 90 \\
\hline Cukup Termotivasi & 6 & 20 & 3 & 10 \\
\hline Kurang termotivasi & 0 & 0 & 0 & 0 \\
\hline Total & 30 & 100 & 30 & 100 \\
\hline
\end{tabular}


Tabel 4. menunjukkan bahwa hasil analisis statistik uji wilcoxon test didapatkan $p=$ 0,102 maka $p<\alpha(0,05)$ dan $\mathrm{H} 1$ diterima artinya tidak terdapat pengaruh antara sebelum dan sesudah diberikan perlakuan pada kelas kontrol. Hasil post test antara kelas kontrol dan kelas eksperiment terdapat di tabel berikut.

Tabel 5. Simpulan Hasil Post test Motivasi Kerja antara Kelompok Kontrol dan Kelompok eksperimen

\section{Test Statistics ${ }^{\mathrm{a}}$}

\begin{tabular}{|l|c|}
\hline & $\begin{array}{c}\text { Post Test } \\
\text { Eksperimen - Post } \\
\end{array}$ \\
& Test Kontrol \\
\hline $\mathrm{Z}$ & $-4.102^{\mathrm{b}}$ \\
Asymp. Sig. (2-tailed) & .000 \\
\hline
\end{tabular}

a. Wilcoxon Signed Ranks Test

b. Based on negative ranks.

Berdasarkan tabel 5. menunjukkan bahwa hasil analisis statistik uji wilcoxon test antara post test kelas kontrol dan kelas eksperimen didapatkan $p=0,000$ maka artinya terdapat pengaruh yang signifikan antara perlakuan yang diberikan pada kelas eksperimen dan kelas kontrol. Faktor-faktor yang mempengaruhi motivasi kerja antara lain; a) prestasi, b) pengakuan, c) pekerjaan itu sendiri, d) tanggung jawab, e) kemajuan, f) pengembangan potensi. Hal tersebut sesuai dengan hasil penelitian lain yang menyatakan bahwa beban kerja, stress kerja dan motivasi kerja secara simultan berpengaruh signifikan terhadap kinerja. Motivasi dapat diartikan sebagai kekuatan (energi) seseorang yang dapat menimbulkan tingkat persistensi dan antusiasmenya dalam melaksanakan suatu kegiatan, baik yang bersumber dari dalam diri individu itu sendiri (motivasi intrinsik) maupun dari luar individu (motivasi ekstrinsik). Motivasi dalam bekerja dipengaruhi oleh dua faktor yaitu faktor motivasi intrinsik yang berasal dari dalam diri individu tersebut yang mendorong dirinya menjadi lebih produktif. Motivasi intrinsik secara langsung berhubungan dengan tingkat ambisi seseorang (8).

John R. Schermerhorn mengemukakan bahwa motivasi untuk bekerja, merupakan sebuah istilah yang digunakan dalam bidang perilaku keorganisasian (Organizational Behavior = OB, menerangkan kekuatan-kekuatan yang terdapat pada diri seseorang individu, yang menjadi penyebab timbulnya tingkat, arah, dan persistensi upaya yang dilaksanakan dalam hal bekerja. Motivasi kerja yang tinggi dapat memengaruhi kinerja seseorang. Seseorang yang memiliki motivasi rendah akan memiliki kinerja yang kurang baik dan sebaliknya seseorang yang memiliki motivasi tinggi akan memiliki kinerja yang baik (9).

Indikator prestasi dijabarkan dengan dengan penilaian objektif terhadap kinerja dari atasan, pemberian kesempatan untuk naik jabatan, dan pengakuan dari rekan kerja, aspek tersebut menjadi bagian yang penting dan dibutuhkan dalam peningkatan motivasi petugas promosi kesehatan. Hal tersebut sesuai dengan hasil penelitian lain bahwa sifat pekerjaan menurut Herzberg merupakan faktor motivasi bagi pegawai untuk berpeforma tinggi. Pekerjaan atau tugas yang memberikan perasaan telah mencapai sesuatu, tugas itu cukup menarik, tugas memberikan tantangan bagi pegawai merupakan faktor motivasi, karena keberadaannya sangat menentukan motivasi untuk berforma tinggi (10).

Faktor - faktor motivasi yang dapat memengaruhi kinerja seseorang yakni motivasi intrinsik dan ekstrinsik. Motivasi tersebut terdiri dari monetary incentives dan non monetary incentives, yang termasuk dalam motivasi monetary incentives yaitu pemberian upah lembur, penghargaan, dan juga tunjangan. Sedangkan yang termasuk dalam motivasi non monetary incentives antara lain lingkungan kerja, kerjasama antar rekan kerja, pengambilan keputusan yang dilakukan oleh pimpinan (11). Ada hubungan antara kepemimpinan dengan motivasi kerja tenaga kesehatan di Puskesmas Kota Yogyakarta dimana gaya kepemimpinan akan menjadi salah satu faktor yang penting untuk menjaga dan meningkatkan motivasi kerja (12). Selain hal tersebut, indikator lain dalam motivasi kerja yakni pekerjaan itu sendiri, yang bearti bahwa petugas promosi kesehatan banyak dipengaruhi oleh faktor ketertarikan terhadap pekerjaan atau adanya minat atau dorongan dari pribadi petugas promosi kesehatan itu sendiri. Ada hubungan bahwa 
semakin tinggi ketertarikan terhadap pekerjaan, semakin tinggi pula motivasinya dalam melaksanakan program promosi kesehatan (13). Kinerja dapat dipengaruhi oleh lingkungan yang kondusif dan adanya kerjasama antar pegawai, hasil penelitian serupa munjukkan hasil bahwa dengan adanya kerjasama antar seluruh pegawai maka akan menciptakan suasana kerja yang kondusif yang dapat memacu pegawai untuk lebih bersemangat dalam menyelesaikan pekerjaannya (14).

\section{Pengetahuan Promosi Kesehatan}

Variabel pengetahuan mempunyai indikator keberhasilan promosi kesehatan di puskesmas dijabarkan menjadi; indikator masukan, indikator keluaran, indikator dampak. analisis dijelaskan sebagai berikut.

\section{Uji Validitas dan Reabilitas Pengetahuan}

Hasil validitas kuesioner penelitian ini yakni $r$ tabel $\geq 0,361$ yang bearti Valid. Hal tersebut sesuai dengan pendapat bahwa syarat jika $r$ hitung $\geq \mathrm{r}$ tabel 0,361 maka data dikatakan valid. Sedangkan jika $r$ hitung $<r$ tabel 0,361 maka data dikatakan tidak valid (14). Hasil uji reliability dipaparkan pada tabel 6 berikut.

Tabel 6. Hasil Reliability Pengetahuan

\begin{tabular}{|c|c|}
\hline Koefisien Alpha & Jumlah Item \\
\hline 0,900 & 31 \\
\hline
\end{tabular}

Tabel 6 menunjukkan bahwa Uji reliability rumus Alpha Cronbach 0,900 atau $\geq 0,60$ maka maka hasilnya reliabel. Hal tersebut sesuai dengan teori bahwa Uji reabilitas penelitian menggunakan Rumus Alpha Cronbach. Sedangkan hasil analisis bivariat pada variabel pengetahuan promosi kesehatan pada kelompok eksperimen ditunjukkan pada tabel berikut.

Tabel 7. Simpulan Hasil Pengaruh Pemberian video AVA Terhadap Pengetahuan Promosi Kesehatan Tenaga Kesehatan di Puskesmas pada Kelompok Eksperimen

\begin{tabular}{lccccc}
\hline & Pengetahuan & \multicolumn{2}{c}{ Sebelum } & \multicolumn{2}{c}{ Sesudah } \\
\cline { 2 - 6 } & n & \% & $\mathbf{n}$ & \% \\
Baik & 27 & 90 & 30 & 100 \\
Cukup & 3 & 10 & 0 & 0 \\
Kurang & 0 & 0 & 0 & 0 \\
Total & $\mathbf{3 0}$ & $\mathbf{1 0 0}$ & $\mathbf{3 0}$ & $\mathbf{1 0 0}$ \\
\hline
\end{tabular}

Tabel 7 menunjukkan bahwa hasil analisis statistik uji wilcoxon test didapatkan $p=0,011$ maka $p<\alpha$ $(0,05)$ dan Ho ditolak artinya terdapat pengaruh yang signifikan sebelum dan sesudah diberikan antara perlakuan pada kelas Eksperimen. Pengetahuan promosi kesehatan responden sebagian besar baik dan meningkat pada pengetahuan kategori baik sebelumnya 90\% meningkat menjadi 100\% dan kategori cukup sebelumnya $10 \%$ dan setelah $0 \%$. Hal tersebut sesuai dengan pendapat bahwa pengetahuan merupakan hasil dari tahu dan ini terjadi setelah seseorang melakukan penginderaan terhadap suatu objek. Penginderaan terjadi melalui pancaindera manusia yakni, indera pendengaran, penglihatan, penciuman, perasaan dan perabaan. Sebagian pengetahuan manusia didapat melalui mata dan telinga dengan menyatakan pengetahuan merupakan segala sesuatu yang diketahui berdasarkan pengalaman manusia itu sendiri dan pengetahuan akan bertambah sesuai dengan proses pengalaman yang dialaminya (15). Hasil uji wilcoxon tes pada variabel pengetahuan promosi kesehatan kelas kontrol ditunjukkan pada tabel berikut. 
Tabel 8. Simpulan Hasil Pengaruh Pemberian Video AVA Terhadap Pengetahuan Promosi Kesehatan Tenaga Kesehatan Di Puskesmas Pada Kelompok Kontrol

\begin{tabular}{lcccc}
\hline Pengetahuan & \multicolumn{2}{c}{ Sebelum } & \multicolumn{2}{c}{ Sesudah } \\
& n & \% & n & \% \\
\hline & & & 29 & 96,6 \\
Baik & 26 & 86,6 & 1 & 3,3 \\
Cukup & 4 & 13,3 & 0 & 0 \\
Kurang & 0 & 0 & & \\
\hline
\end{tabular}

Wilcoxon Test

$P$ Value $=0,041$

Tabel 8. di atas menunjukkan bahwa hasil analisis statistik uji wilcoxon test didapatkan $p=$ 0,041 maka $p<\alpha(0,05)$ dan H0 ditolak artinya terdapat pengaruh yang tidak terlalu signifikan antara sebelum dan sesudah diberikan perlakuan pada kelas kontrol. Hasil variabel pengetahuan dengan sebagian besar baik yakni 86,6 \% dan kategori cukup sebanyak 13,3\%, kenaikan tidak terlalu signifikan sebesar hanya $10 \%$. Pemberian intervensi di video pada kelompok kontrol tidak menjabarkan meteri indikator keberhasilan pelaksanaan promosi kesehatan di Puskesmas. Hasil post test motivasi kerja antara kelompok kontrol dan kelompok eksperimen dipaparkan dalam tabel berikut ini.

Tabel 9. Hasil Post Test Pengetahuan Antara Kelompok Kontrol dan Kelompok Eksperimen

Test Statistics ${ }^{\mathrm{a}}$

\begin{tabular}{|l|r|}
\hline & $\begin{array}{c}\text { Post Test Eksperimen - } \\
\text { Post Test Kontrol }\end{array}$ \\
\hline $\mathrm{Z}$ & $-4.485^{\mathrm{b}}$ \\
Asymp. Sig. (2-tailed) & .000 \\
\hline
\end{tabular}

a. Wilcoxon Signed Ranks Test

b. Based on negative ranks.

Tabel 9 menunjukkan bahwa hasil analisis statistik uji wilcoxon test antara post test kelas kontrol dan kelas eksperimen didapatkan $p=0,000$ maka artinya terdapat pengaruh yang signifikan antara perlakuan yang diberikan pada kelas kontrol dan kelas eksperimen. Penggunaan media promosi kesehatan berbasis digital sangat berpengaruh pada peningkatan pengetahuan petugas promosi kesehatan.

Indikator keberhasilan diperlukan untukmemantau dan mengevaluasi promosi kesehatan di puskesmas. Oleh karena itu, capaian indikator keberhasilan menjadi perhatian dari pemerintah daerah sebagai pembina puskesmas. Indikator keberhasilan terdiri dari; 1) indikator masukan (input); yang meliputi komitmen, sumber daya manusia, sarana/peralatan, dan dana; 2) indikator proses yangmeliputi proses pelaksanaanp romosi kesehatan puskesmas yang meliputi promosi kesehatan di dalam gedung dan di masyarakat; 3) indikator keluaran (output) meliputi keluaran dari kegiatankegiatan yang dilak sanakan, baik secara umum seperti keterlibatan semua tenaga kesehatan puskesmas telah melaksanakan promosi kesehatan maupun secara khusus seperti banyaknya pasien atau klien yang sudah terlayani oleh berbagai kegiatan promosikesehatan dalam gedung (konseling, biblioterapi, dll). Pengetahuan menjadi faktor penting yang didapatkan dari informasi atau bimbingan dari petugas, pelatihan yang sudah diikuti, pengalaman selama bekerja karena sebagian besar para pekerja bekerja dengan kurun waktu yang cukup lama yaitu $>1$ tahun. Jika dilihat dari tingkat pendidikan sebagian besar petugas berlatar pendidikan Strata 1/ S1. Hal tersebut sesuai dengan hasil penelitian sebelumnya bahwa perlu adanya peningkatan kemampuan petugas maupun pengadaan media pendukung penyebaran informasi kesehatan dengan bantuan teknologi terutama pada penggunaan dan pemanfaatan teknologi berbasis internet. Petugas yang telah mengetahui makna dan tujuan, strategi dasar promosi kesehatan maupun pengetahuan mengenai PHBS yang baik akan mampu meningkatkan kinerja petugas dalam meningkatkan cakupan PHBS rumah tangga yang ada. Hal ini disebabkan pengetahuan yang baik mampu memberikan rujukan tindakan yang ideal untuk dilakukan sehingga pengetahuan yang baik akan mampu membuat petugas kesehatan mampu secara maksimal dalam melakukan kinerjanya dan terus meningkatkan kinerja tersebut (16). 
Penelitian serupa menunjukkan hasil bahwa terdapat hubungan antara promosi kesehatan puskesmas dengan capaian PHBS dengan nilai signifikan. Penelitian kualitatif menunjukkan bahwa peran promosi kesehatan puskesmas dalam capaian PHBS dapat diwujudkan melalui serangkaian program promosi kesehatan yaitu kunjungan rumah, pemberdayaan melalui kemitraan, serta pengorganisasian melalui Upaya Kesehatan Berbasis Masyarakat (UKBM) (17). Kecakapan petugas promosi kesehatan dalam penyebarluasan informasi dan perancangan media sangat penting dalam pengaruh edukasi pada masyarakat disebabkan karena rendahnya pengetahuan, pengalaman, dan keterampilan petugas, sehingga berdampak pada cakupan program promosi kesehatan belum mencapai standar nasional (18). Peningkatan pengetahuan dapat dilakukan dengan memberikan pelatihan, seminar di setiap Puskesmas pada hari-hari tertentu. Perlu dilakukan peningkatan pengetahuan karena sangat erat hubungannya dengan tingkat pendidikan. Sumber daya berperan penting dalam implementasi kebijakan seperti sumber daya manusia, sumber daya keuangan maupun sarana prasarana yang mendukung pelaksanaan kegiatan promosi kesehatan di puskesmas tersebut. Ketiga sumber daya tersebut maka akan sangat mempengaruhi keberhasilan implementasi promosi kesehatan di puskesmas.

\section{KESIMPULAN DAN SARAN}

Penelitian ini menunjukan bahwa adanya pengaruh pada pemberian media Video AVA terhadap peningkatan motivasi kerja dan pengetahuan tenaga promosi kesehatan tentang indikator keberhasilan dalam pelaksanaan promosi kesehatan di Puskesmas. Media video AVA mampu memberikan pengaruh yakni membantu menstimulasi terhadap apa yang dilihat dan didengar dalam proses penerimaan pesan. Pemberian Video Audio Visual Aids (AVA) memudahkan seseorang dalam mengingat, menggunakan gambar yang membuat seseorang lebih fokus, gselain itu gambar dapat mempengaruhi emosional pembaca.

\section{UCAPAN TERIMAKASIH}

Ucapan terima kasih pada pihak Dinas Kesehatan Kota Banjarbaru, puskesmas di wilayah Kota Banjarbaru dan DPMPTSP Kota Banjarbaru Kalimantan Selatan yang telah memberikan ijin untuk melakukan penelitian.

\section{DAFTAR PUSTAKA}

1. Kemenkes RI. (2011). Standart Promosi Kesehatan di Puskesmas.Jakarta: Kemenkes

2. Kemenkes RI. (2013). Pedoman Pelaksanaan Promosi Kesehatan Di Puskesmas. Jakarta: Pusat Promosi Kesehatan.

3. Suwanto. (2019). Pengaruh Disiplin Kerja Dan Motivasi Kerja Terhadap Kinerja Karyawan Pada Rumah Sakit Umum Tangerang Selatan. JENIUS , Vol. 3, No. 1.

4. Naish, J., \& Syndercomb, C. D. (2014). Audio Visual Aids. Medical sciences (2 ed.) , p. 562. ISBN 9780702052491.

5. Notoatmodjo, S. (2012). Metodologi Penelitian Kesehatan. Jakarta: Rineka Cipta. Jakarta: Rineka Cipta.

6. Sujarweni, V. W. (2014). SPSS untuk Penelitian. Yogyakarta : Pustaka Baru Press

7. WHO. (2014). Global status report on noncommunicable disease 2014: Attaining the nine global noncommunicable disease targets, a shared responsibility. Geneva, Switzerland: WHO.

8. Marquis, B. L., \& Huston, C. J. (2010). Kedisiplinan dan Kepemimpinan dalam Kepemimpinan dan Manajemen Keperawatan Teori dan Aplikasi (Edisi ke4). Jakarta: EGC

9. Natasia, N., L, A., \& K, J. (2014). Faktor yang Mempengaruhi Kepatuhan Pelaksanaan SOP Asuhan Keperawatan di ICU-ICCU RSUD Gambiran Kota Kediri. Jurnal Kedokteran Brawijaya. , 28(1):21-25.

10. Nasir, Andi., \& Sabrina . (2019). Analisis Pengaruh Motivasi Terhadap Kepuasan Kerja Tenaga Penyuluh Kesehatan Paad Dinas Kesehatan Kota Parepare. Jurnal Ilmiah 
Manusia dan Kesehatan, Umpar, Volume 2,

Nomor 1, Halaman 180-181

11. Al-Hawary SIS, S., \& NA, E.-F. B. (2017). Impact of Motivation on Job Performance of Nursing Staffin Private Hospitals in Jordan. International Journal of Academic research in Accounting, Finance and Management Sciences, 7(2):54-63.

12. Rumitasari, H. (2020). Kepemimpinan dan Motivasi Kerja Tenaga Kesehatan di Puskesmas Kota Yogyakarta. Jurnal Kesehatan Masyarakat Indonesia, UNIMUS, Volume 15, Nomor 1, Halaman 47-51.

13. Suhenda, Andi. (2018). Faktor-faktor Yang Berhubungan Dengan Motivasi Penugasan Promosi Kesehatan Puskesmas Pelaksanaan Program PHBS di Sekolah Dasar. Jurnal Persada Husada Indonesia, Jurnal Stikesphi, Volume 5, Nomor 18, Halaman 60-69.

14. Aditya, H., Sudirman., Andri, M. (2018). Hubungan Kepemimpinan dan Lingkungan Kerja dengan Kinerja Pegawai di Puskesmas Mabelopura Kota Palu. Jurnal Kolaboratif Sains. Vol 1, No 1, Hal 12-20

15. Jatmika, S. d. (2019). Perbedaan Edukasi Konsumsi Sayur Dan Buah Pada Anak SD Menggunakan Metode Ceramah Dengan Alat Peraga Dan Media Audiovisual. Jurnal Gizi Indonesia Vol.42 No.1, Hal 55-62.

16. Lestari, S., \& Iwan Stia Budi, R. M. (2016). Analisis Kinerja Petugas Promosi Kesehatan Puskesmas Dalam Meningkatkan Cakupan PHBS Rumah Tangga Di Wilayah Kerja Dinas Kesehatan Kota Palembang. Jurnal Ilmu Kesehatan Masyarakat, 7-15.

17. Sari Intan IK, Muji Sulistyowati. (2015). Analisis Promosi Kesehatan Di Puskesmas Kalijudan Terhadap Phbs Rumah Tangga Ibu Hamil. Jurnal Promkes, Vol. 3, No. 2 Desember 2015: 159-170. Departemen Promosi Kesehatan dan Ilmu Perilaku Fakultas Kesehatan Masyarakat, Universitas Airlangga Surabaya

18. A'yunin, Elia Nur., Gamelia Elvira., \& Masfiah Siti. (2018). Pengaruh Pelatihan Pengembangan Media Promosi Kesehatan Ibu Hamil Terhadap Pengetahuan dan Keterampilan Pada Petugas Penyuluh Kesehatan di Kabupaten Banyumas. Jurnal Kesmas Indonesia, Volume 10, Nomor $1,1-12$ 